Document downloaded from:

http://hdl.handle.net/10251/120545

This paper must be cited as:

Balaguer-Puig, M.; Marqués-Mateu, A.; Lerma, JL.; Ibañez Asensio, S. (2018). Quantifying small-magnitude soil erosion: geomorphic change detection at plot scale. Land Degradation and Development. 29(3):825-834. https://doi.org/10.1002/ldr.2826

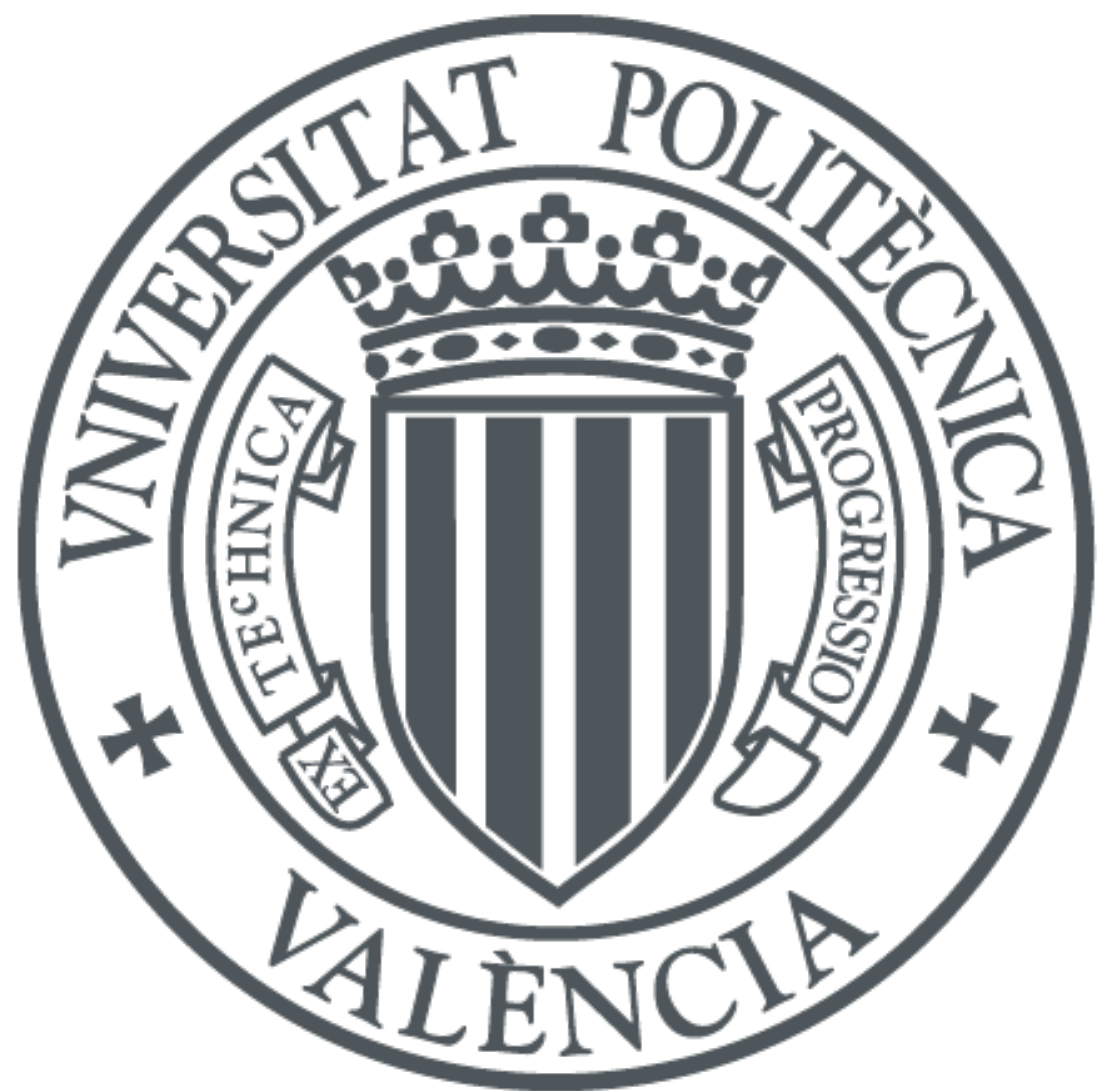

The final publication is available at

http://doi.org/10.1002/ldr.2826

Copyright John Wiley \& Sons

Additional Information 


\title{
QUANTIFYING SMALL-MAGNITUDE SOIL EROSION: GEOMORPHIC CHANGE DETECTION AT PLOT SCALE
}

\author{
Matilde Balaguer-Puig ${ }^{1, \star}$, Ángel Marqués-Mateu ${ }^{1}$, José Luis Lerma1, Sara Ibáñez-Asensio²
}

${ }^{1}$ Department of Cartographic Engineering, Geodesy and Photogrammetry, Universitat Politècnica de València, Spain

${ }^{2}$ Department of Plant Production, Universitat Politècnica de València, Spain

* Corresponding author: Matilde Balaguer-Puig (balaguer@upv.es), Department of Cartographic Engineering, Geodesy and Photogrammetry, Universitat Politècnica de València, Camino de Vera, s/n, 46022 Valencia (Spain)

Abstract

Soil erosion is a big concern in bare soils from burnt areas and agricultural lands that lack a vegetation cover. In those unprotected soils, intense rain episodes, typical in Mediterranean climate, cause severe soil erosion processes that have been well studied previously using a number of procedures, such as the Geomorphic Change Detection (GCD) method. This method uses Digital Elevation Models (DEMs) of the soil surface and determines the morphological changes in terms of both erosion and deposition by DEMs of Difference (DoDs). However, some types of soil erosion, such as diffuse and sheet erosion, may have a small magnitude, at a millimetre scale, and their determination requires methods adapted to that scale. In this paper we analyse the suitability of the GCD method to account for small magnitude soil erosion. We present a laboratory procedure and setup to represent and quantify sediment budget in small experimental soil plots through differences of DEMs obtained from images using photogrammetric Structure from Motion (SfM). This study explores several key aspects of the technique: establishment of a common reference system for DEMs; determination of errors in the generation of DEMs; selection of appropriate criteria to obtain reliable changes in DoDs; error propagation using Monte Carlo simulation; and validation of the procedure by comparing the results with actual sediments collected during the experiment. Results showed an overestimation of $13 \%$ in accumulated soil loss and confirmed that GCD approach with SfMbased DoDs is a suitable method to quantify small-magnitude erosion events.

\section{Keywords:}

Water soil erosion; Structure from Motion (SfM) photogrammetry; Digital Elevation Model (DEM); DEMs of Difference (DoD); Geomorphic Change Detection (GCD)

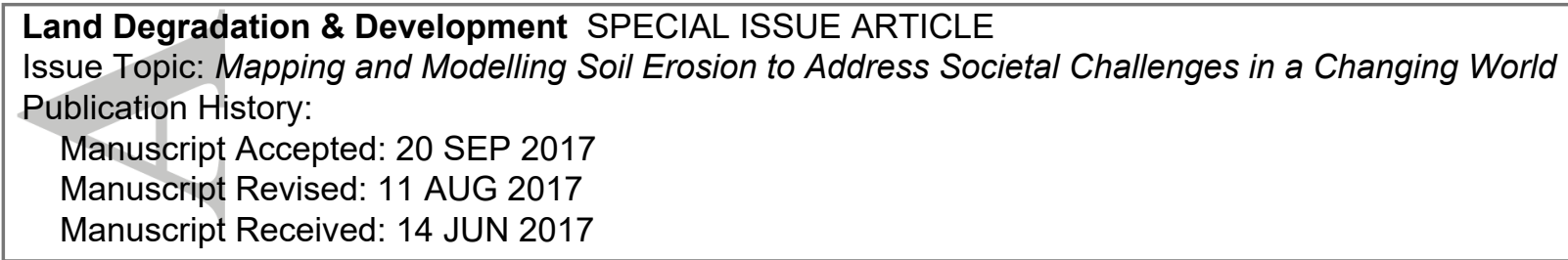

This article has been accepted for publication and undergone full peer review but has not been through the copyediting, typesetting, pagination and proofreading process which may lead to differences between this version and the Version of Record. Please cite this article as doi: 10.1002/ldr.2826 


\section{Introduction}

Soil erosion has been identified as one of the most serious threats to agriculture sustainability. According to the 'State of the World's Soil Resources' report (FAO, 2015), erosion processes remove 25 to 40 billion tonnes of arable land per year worldwide, and projections indicate a yield reduction of more than 253 million tonnes by 2050 .

The immediate consequence of this scene is the significant decline of crop yields and soil capacity to complete the carbon, nutrient, and water cycles.

The negative impacts of soil erosion on food security and land degradation have long been a concern for government organisations. The first attempts to establish the magnitude of the problem were posed in 1977 during the United Nations Conference on Desertification (UNCOD), in Nairobi. A pioneering world map of desertification was prepared for that event, and afterwards, UNEP developed a methodology for evaluating and mapping desertification in response to requests for more precise data on desertification and its evolution (FAO/UNEP/UNESCO, 1979; FAO, 1980; UN, 1978). From then on, FAO, USDA and CEE periodically distribute monitoring and evaluation reports on the evolution of land degradation and implement programmes to support environmentally related decision making. However, despite the urgent need for monitoring and predicting soil changes, most countries and states lack national soil information systems, such as those created for economic, climate, or water resources management. Policies for the recovery of degraded soils, the implementation of soil conservation measures, and technological advances may reduce or prevent most of the negative impacts of agriculture, but it is essential to evaluate the effectiveness of soil erosion control practices in a reliable and continuous way over time. However, despite the important technological advances and the continuous efforts carried out during the last 40 years, there is not yet an effective tool able to achieve this neat aim, which is precise soil loss quantification. An important number of methods to quantify soil loss exist (Morgan, 2005), although in most of cases, they are difficult to implement at wide-scale owing to conflicts between public and private interests, the great variety of organisations involved in soil management policies (from national to local), and other economic constraints (FAO, 2015).

All of these circumstances led to a new approach to conduct land and soil degradation mapping projects when compared to classical methods. Because the problem of soil erosion is primarily found at discrete locations (Bruinsma, 2003), the workflow might be more efficient with a bottom to top approach, that is, from small areas (plot, slope) to wide areas (watershed, regional). In the last decade, land degradation maps are aimed at representing land degradation at three different spatial scales, namely local, national and global (CDE/WOCAT FAO/LADA ISRIC, 2008). Within this trend, the focus is on local scale studies, because it is the first step towards global mapping. Current methodologies include land management systematic surveys, together with the use of maps and satellite images to document either the success or failure of the implemented techniques. 
It is in this framework that new, cost effective soil erosion measuring techniques achieve relevance and interest, and thereby, novel approaches may contribute to better understanding the complexity of erosion processes. In this line, we present a rigorous laboratory method, based on the Geomorphic Change Detection (GCD) concept and convergent photogrammetry, that may be used in conjunction with (and with support of) other methods to calculate soil erosion at different scales.

The morphological approach (Ashmore \& Church, 1998) allows for the assessment of sediment balances from geomorphological changes in the terrain surface. GCD (James et al., 2012) can be conducted using differences between DEMs that represent topographic surfaces at different time (Brasington \& Smart, 2003; Lane et al., 2003). The DEM of Difference (DoD) technique (Wheaton et al., 2010) is fairly simple and can be easily implemented within a Geographic Information System (GIS) environment. We can find many application examples of GCD and DoD to assess sediment budgets in fluvial geomorphology, most of them based on the work carried out by Wheaton et al. (2010) and subsequents. We will focus on the use of GCD in soil water erosion studies at microscale.

DEMs used in geomorphological studies are built from 3D data collected with a variety of surveying techniques and instruments (Carrivick et al., 2016): total stations (TS), differential Global Navigation Satellite Systems (GNNS), aerial laser scanning (ALS), terrestrial laser scanning (TLS), classical photogrammetry and, more recently, Structure from Motion (SfM) photogrammetry. In the last years, the applications of SfM with Multi-View Stereo (MVS) at different scales has considerably increased in the geosciences (Eltner et al., 2016; Fonstad et al., 2013; James \& Robson, 2012; Micheletti et al., 2015; Westoby et al., 2012). SfM photogrammetry has been evaluated at micro-scale, confirming that this technique can provide high precision DEMs (e.g. Kasprak et al., 2015; Micheletti et al., 2014; Nouwakpo et al., 2014) and, indeed, it is being used in recent GCD-based soil erosion research (e.g. Balaguer-Puig et al., 2017; Guo et al., 2016; Hänsel et al., 2016; Prosdocimi et al., 2017; Vinci et al., 2017). Validation of the erosion estimates obtained with the morphologic method is done by comparison with the actual sediments collected during the experiment.

A key aspect of the technique is the determination of the DEM errors. Carrivick et al. (2016) and Eltner et al. (2016) published detailed bibliographic surveys and analysed the main photogrammetric factors affecting the error in SfMMVS generated point clouds, including scale/distance, camera calibration, image network geometry, image matching performance, surface texture, lighting conditions and Ground Control Point (GCP) characteristics. Other experimental approaches rely on Monte Carlo methods to find out the effects of errors in SfM factors, e.g. camera parameters (Nouwakpo et al., 2014), number and quality of GCPs, or precision in image measurements (James et al., 2017a, 2017b) on the output DEMs. DEM errors themselves also affect the final outcomes of the GCD computations due to error propagation through GIS spatial operations on DEMs (Heuvelink, 1998; Wechsler \& Kroll, 2006). It is thus necessary to distinguish true morphologic changes from noise associated to DEM errors, usually establishing a minimum Level of Detection (LODMIN) (Brasington et al., 2003; Milan et al., 2011; Wheaton 
et al., 2010; Williams, 2012). A common approach to computing the error propagation in GIS analytical functions is based on the Monte Carlo method, which adds random error components to input layers (parameters) and repeats calculations a number of times (Wechsler \& Kroll, 2006). This sample of outputs allows users to compute statistics and find out the effects of error propagation on the final results (Hengl et al., 2010). In this paper we used the Monte Carlo method to determine uncertainties in the sediment budget obtained with the GCD method in erosion laboratory experiments.

Based on the above previous research and bearing in mind their results, we seek to establish a working procedure to determine soil loss with the GCD method in laboratory experiments at micro-scale. We specifically focus on finding rigorous strategies to create high precision DEMs from images with the aim of detecting millimetric changes. Those DEMs and their uncertainties determined with the Monte Carlo method will be used to test the efficiency and validity of the GCD method. This procedure should be regarded as the first step in converting the well stablished SfM-based DoD technique into a valid field tool for monitoring and mapping purposes in soil erosion research.

\section{Methodology}

In this section we describe the different stages of GCD procedure using DoD in laboratory experiments, and its application to a case study. A typical geomorphological study based on DoDs has the following main stages: image data acquisition, dense point cloud creation, DEM generation, DoD computation and reclassification, and error propagation analysis. In this paper, we extend the usual workflow with some relevant stages such as the accurate establishment of the Coordinate Reference System (CRS) with signalled GCPs, the runoff collection and processing in each rainfall event, and the comparison of the weight of the collected sediments with the soil loss estimates. Figure 1 shows a schematic view of the procedure.

\subsection{Rainfall simulation and data acquisition}

Rainfall simulators are aimed at reproducing the characteristics of rainfall as closely as possible. We can find different designs for field or indoor use, or both (Cerdà et al., 1997). In the laboratory, the setup includes a box, filled with a soil sample, with a gathering system that allows the collection of runoff and infiltration during the rain episode. Both water and suspended sediment collected are then processed by standard laboratory methods of filtering, oven-drying at $105^{\circ} \mathrm{C}$ and weighting, obtaining the weight of the sediments transported by runoff. The bulk density $\rho_{b}$ of the soil sample in the box is obtained by the standard core method (Hao et al., 2008).

\subsection{Coordinate Reference System (CRS) setup}

A crucial element in the process of detecting morphological changes is the setup of a unique, common CRS, which allows users to achieve a perfect relative georeferencing across DEMs (Williams, 2012). The CRS must be set through a set of GCPs located in fixed and stable locations, with precise coordinates measured by rigorous 
surveying methods. GCPs must be distributed throughout the study area, arranged at different depths and not aligned.

\subsection{Image acquisition}

The photogrammetric method used to obtain point clouds determines the proper design of the image acquisition procedure and the final precision of the computed 3D points. In order to achieve the best precision, the setup must include highly redundant convergent images, an adequate camera-object distance, good illumination conditions, availability of GCPs and known calibration parameters of the camera, usually determined by self-calibration in a bundle adjustment (James \& Robson, 2014; Mosbrucker et al., 2017). To obtain redundant convergent images for 3D modelling, a typical way is to take ring distributed photos around the object, with overlaps between consecutive images up to $80 \%$ (Wenzel et al., 2013). Besides, a network image geometry suitable for measuring flat objects, such as the soil box surface, should have vertical viewing angles of $\sim 45^{\circ}$, producing angles between photos $\sim 90^{\circ}$ that provide the highest accuracy in photogrammetric point measurement (Luhmann et al., 2013).

\subsection{SfM-MVS point clouds and DEM generation}

The SfM-MVS sequence generates dense 3D point clouds from the set of images. A bundle adjustment estimates image positions and 3D point coordinates of tie points, with arbitrary scale and orientation, but they can be transformed to a given datum with known GCPs. The identification and measurement of GCPs can be performed on the initial images or on the cloud of points obtained, although measurements in the images are more reliable (James \& Robson, 2012). It is highly recommended to create digital masks to isolate the areas of interest on the pictures and to improve the results of MVS algorithm. Self-calibration is usually performed to obtain camera model parameters.

DEMs are created from point clouds using interpolation methods. In geomorphological applications, the choice of a particular spatial interpolation method depends on the characteristics of the terrain and the distribution of the measured points (Fisher \& Tate, 2006). The inverse distance weighting (IDW) method is robust to errors in the coordinates, create lesser smoothed DEMs and is precise (Liu et al., 2011). It is a proper solution in the GCD approach, because soil surface changes are best determined with lesser smoothed DEMs that keep local variations intact. The accuracy of the interpolation method can be determined by split-sample validation, which is appropriate when an independent set of sample data is not available (Erdogan, 2009). That is the case in rain simulation studies in which it is impossible to place permanent check points on the soil surface without affecting the phenomenon under study (Heng et al., 2010).

An estimate of the error affecting the DEMs can be the quadratic composition of the georeferencing error $E_{T}$ (the RMSE of the GCPs used in the bundle block adjustment) and the interpolation error $E_{1}$, the two main production stages of DEM (Li et al., 2005):

This article is protected by copyright. All rights reserved. 
$E_{D E M}=\sqrt{{E_{T}{ }^{2}+E_{I}^{2}}^{2}}$

\subsection{DoD and change detection}

The detection and quantification of geomorphological changes over time can be performed through comparison of DEMs surfaces at each time point. Two DEMs with the same dimensions are subtracted on a cell-by-cell basis giving a DoD or map of differences. Volumes of erosion and deposition correspond to negative and positive difference values respectively. Using the bulk density value, weights corresponding to erosion, deposition and net soil loss can be determined.

The computation of morphological changes from DoDs deserves special attention to discriminate true changes from noise originated in the input surface errors. The Minimum Level Of Detection (LODMIN) is the error in DoD $\left(E_{D \circ D}\right)$ derived from the difference of two DEMs (Williams, 2012), and may be a suitable threshold discriminating criterion in small areas and low intensity rainfall (Gessesse et al., 2010; Hänsel et al., 2016):

$L O D_{M I N}=E_{D O D}=\sqrt{E_{D E M_{1}}^{2}+E_{D E M_{2}}^{2}}$

where $E_{D E M 1}$ and $E_{D E M 2}$ are the individual errors in the two DEMs, obtained from equation [1].

\subsection{Error propagation and uncertainty of the estimated soil loss}

The random errors in input DEMs propagate into volume and weight values of soil loss obtained as a result of map algebra operations. The Monte Carlo method can be used to assess the uncertainty due to random errors in DEMs. This approach considers that a DEM is only one of the possible realisations of the true elevation surface. So, we can obtain multiple simulations of DEM -adding some sort of perturbation to the original variable- to create a sample distribution and analyse their statistics. This method is commonly used when ground-truth data is not available, and when we only have an estimation of RMSE, which does not represent the spatial structure of the error (Heuvelink, 1998, 2005; Wechsler \& Kroll, 2006).

In this procedure, the Monte Carlo method is used to obtain simulated DoDs by adding random error fields to the two original DEMs, based on DEM errors obtained from [1]. In order to obtain the uncertainty in the weight of soil loss calculated from volume, simulated values of bulk density are considered, by adding a random error to the measured density based on the accuracy of the core method (Raper \& Erbach, 1987). The Monte Carlo method needs a significantly large number of realisations to produce a reliable estimate of the distribution function, at least 100 (Hengl et al., 2010). A set of DoD instances are obtained and basic statistics, essentially mean $(\mu)$ and standard deviation $(\sigma)$, of volume and weight variables, are computed. The ultimate outcome of the process is the uncertainty associated to soil loss computations.

This article is protected by copyright. All rights reserved. 


\subsection{Case study}

In this section we briefly describe a case study that supports the laboratory procedure proposal. All the pictures and data were collected in a previous experiment conducted by Balaguer-Puig et al. (2017), even though the pictures were completely reprocessed to obtain the results presented in this paper.

In the experiment we use a small soil sample box of $0.68 \times 0.75 \mathrm{~m}$ with a uniform slope of $10 \%$, with sandy loam texture without vegetation cover during several simulated rainfall episodes. GCPs were placed on the simulator structure and signalled with dot and line shaped targets (Fig. 2). The local CRS was defined using a precision steel rule, placed in vertical position, that determined the scale and the vertical axis of the CRS. Two total stations were used to collect horizontal and vertical angles to the GCPs. A computer program was specifically written for this study to perform a sequence of operations consisting of 3D resections and intersections that gives the $X Y Z$ coordinates of the observed points. A second rule was used to check the accuracy of the survey by comparing the nominal and the observed length values. The difference between the two lengths gave submillimeter values $(0.2$ $\mathrm{mm})$, thus showing the high quality of the method.

Five rainfall simulations of 15,30 and 60 minutes and $30 \mathrm{~mm} / \mathrm{h}$ intensity were carried out. During each episode we systematically collected all runoff and infiltration generated in the plot. The weight of the sediments transported by runoff was obtained by standard laboratory methods. The bulk density was determined twice, before initial and after last rain simulations.

Images of the soil surface were taken before and after rain episodes. We used a Canon EOS 1100D digital camera with a fixed focal length of $18 \mathrm{~mm}$. The pictures (between 11 and 15) were taken around the simulation table at 0.5 $\mathrm{m}$ with an approximate vertical angle of $45^{\circ}$, using a tripod to get better results (Fig. 3 and Fig. $4 \mathrm{a}$ ). In order to improve the adjustment geometry, some photographs were taken at different heights. The ground sampling distance (GSD) was $0.28 \mathrm{~mm}$ at a distance of $0.5 \mathrm{~m}$.

Point clouds were created using the SfM-MVS software Agisoft PhotoScan Professional version 1.3.1 (Table 1 and Fig. 4b). We set the coordinate reference system using eight GCPs that were measured on the images (Fig. 3). A DEM with $1 \mathrm{~mm}$ cell size was created from the dense point clouds using the IDW interpolation method in the ArcGIS environment. We determined the height interpolation error by the split-sample technique, using a random selection of $5 \%$ of the original point cloud as check points.

DoDs were obtained by difference of two DEMs (Fig. 4c). The LODMIN values were computed with equation (2) and used to classify the differences in erosion and deposition categories (Fig. 4d). The counting of cells in each category gave the final outcomes: area, volume and sediment weight.

The uncertainties of those calculated values were obtained from Monte Carlo simulations. Using a simulation computer program written in Python for this study, we created raster images containing random values from the 
DEM error distribution, then added each random raster to its corresponding DEM surface, and computed the DoD with the randomised DEMs. Besides surface errors, the uncertainty of the bulk density was also included in the simulations. It has been reported that the method used to determine the bulk density (core method) has an estimated standard deviation $\sigma=0.04 \mathrm{~g} / \mathrm{cm}^{3}$ (Raper \& Erbach, 1987); which allowed us to create a random sample of bulk density perturbations that were used in the simulation. Several simulations were run with a number of realisations ranging from 10 to 500 . Finally, we computed basic statistics of the volume and weight variables, obtaining the uncertainty as an error interval based on $3 \sigma$ limits (99.7\% confidence).

\section{Results}

The average point density of the photogrammetric point clouds was 140 point $/ \mathrm{cm}^{2}$ with an approximate regular spacing of $1.2 \mathrm{~mm}$. This high point density allows us to create high resolution DEMs with $1 \mathrm{~mm}$ cell size, without adding unwanted smoothness to the surface representation.

The georeferencing error of the five point clouds is estimated with the RMSE of the GCPS (since it represents the relative accuracy of the $3 \mathrm{D}$ model), with values ranging from 0.525 to $0.960 \mathrm{~mm}$. The interpolation error in the creation of the DEMs is $\sim 0.1 \mathrm{~mm}$. The total DEM error is obtained according to Equation (1), and ranges from 0.535 to $0.976 \mathrm{~mm}$. The LODMIN value is equal to DoD error (Equations 2 and 3), with values from 0.762 to $1.205 \mathrm{~mm}$ (Table 2).

Table 3 shows the outcomes of the DoD classifications in terms of erosion, deposition and net change categories. All the values were first computed without applying any criterion to discriminate changes (i.e. straight DEM differences), and then applying LODMIN as the minimum threshold. The volume estimates considering the LOD threshold can be up to $78 \%$ smaller than those from direct differences. Volume changes obtained from DoDs were converted to weight units using the measured bulk density value.

The collected runoff sediment weight was $388.4 \mathrm{~g}$, and with infiltration $(26 \mathrm{~g})$, the total sediment weight collected was $414.4 \mathrm{~g}$. The bulk density was determined before the rain experiment and we obtained a value of $1.43 \mathrm{~g} / \mathrm{cm}^{3}$; after all rain simulations, we made another measurement and obtained a value of $1.45 \mathrm{~g} / \mathrm{cm}^{3}$, which shows a slight increment of $0.02 \mathrm{~g} / \mathrm{cm}^{3}(1.4 \%)$, which is below the experimental error of the core method (Raper \& Erbach, 1987). The uncertainty of soil loss values calculated from DoDs was obtained with a series of simulations conducted with the Monte Carlo method (Table 4). Table 5 and Figure 5 represent the mean values and error intervals of soil loss weight.

\section{Discussion}

The outcomes of the Monte Carlo method show that the GCD method is very accurate, provided that previous photogrammetric measurements and the determination of the CRS have been carried out rigorously. It is interesting to note that most of the error values related to sediment weight come from the uncertainty in the bulk density, not 
from the DEMs. In fact, the execution of the Monte Carlo method considering an error free bulk density value gave smaller error bounds.

Figure 5 shows agreement between collected and computed sediments. Morphological estimates from Monte Carlo simulations are greater than collected values in the three first episodes, with an overestimation of $13 \%$ in accumulated soil loss ( $7 \%$ if we consider sediment collected in infiltration). Similar soil loss overestimation has been reported in previous laboratory studies which is usually attributed to soil settling within the simulation box (Rieke-Zapp \& Nearing, 2005), bulk density changes due to raindrop compaction (Armstrong et al., 2011; Gessesse et al., 2010; Hänsel et al., 2016; Heng et al., 2010), or both (Gordon et al., 2012). In our study, the soil sample was carefully prepared to avoid collapse during the experiment, but even so, a small settling is still possible. The morphological sediment estimations with the GCD procedure presented in this paper can be considered satisfactory.

There are few studies in the literature that quantify the accuracy of DoD-based sediment estimations in relation to actual soil loss. Most laboratory studies that carry out morphological erosion estimations verify their results with estimations calculated from sediment concentration sampling. Rieke-Zapp and Nearing (2005) consider that soil settling represents $29 \%$ of the calculated sediments, but do not provide information on the volumetric estimations in the DoD technique nor they include the amounts of sediments transported by runoff. Prosdocimi et al. (2017) report that soil loss estimated from DoDs are two orders of magnitude higher than those estimated by runoff sampling. Hänsel et al. (2016) also use sediment concentration sampling for soil loss estimation and obtain differences of $14.7 \%$, but they previously apply a height correction to the DoD cell values to compensate for supposed soil compaction. Guo et al. (2016) report very similar results from photogrammetric observations and runoff and sediment collections, although they use bar scales instead of GCPs to define the CRS; they do not assess DEM errors, and do not apply any technique for discriminating actual changes in DoDs either. Vinci et al. (2017) also conclude that SfM estimates the measured soil loss correctly, but they apply a soil-dependent procedure to estimate runoff and soil loss that needs a previous calibration phase, and shows great differences between SfM and TLS soil loss estimations.

As it can be seen in the above discussion, there is not full agreement amongst authors, either in the experimental results or in the standard methodology. It seems clear that the application of the GCD method to high precision erosion studies is an open question, which actually led us to conduct this study. We believe that our contribution focuses on the geometric issues that are not usually discussed in the literature. Therefore, if users pay attention to the definition of the CRS and the right image acquisition layout, they can be fairly sure that soil loss uncertainties achieved with this approach are due to factors other than photogrammetric or geometric ones. In this sense, the results are promising, but future models will have to take into account additional factors.

This article is protected by copyright. All rights reserved. 


\section{Conclusions}

In this paper we present a working procedure aimed at determining sediment volumes of small magnitude using DoDs from SfM-derived DEMs. Sediment estimates were compared to actual sediment collected during the rainfall simulations in the laboratory.

Regarding the image-based point cloud generation, a strong network image geometry, with multiple convergent and oblique images, provides the best photogrammetric accuracy in case of roughly flat objects such as the soil surface.

A key point was the accurate definition of a set of GCPs which provided a unique CRS for all DEMs and DoDs, and increased the precision and consistence of the 3D coordinates of the point clouds. The error propagation analysis by Monte Carlo simulations gave very small error bounds, which proves the high potential of the method.

The outcomes of the procedure showed good agreement with actual data, with a slight overestimation that may be due to some edaphic issues (e.g. soil settling or bulk density variations) that deserve further research. Likewise, future studies might complement this procedure by adding other factors or variables involved in runoff generation such as surface roughness or sediment connectivity.

In summary, the procedure proved to be suitable to estimate sediments transported by runoff in laboratory experiments, even with soft rain simulations, and fits very well in an interdisciplinary framework to gain more insight in processes driving soil water erosion.

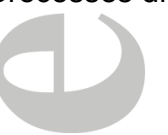

\section{References}

Armstrong A, Quinton JN, Heng BCP, Chandler JH. 2011. Variability of interrill erosion at low slopes. Earth Surface Processes and Landforms 36: 97-106. DOI: 10.1002/esp.2024

Ashmore PE, Church MA. 1998. Sediment transport and river morphology: a paradigm for study. In: Klingeman PC, Beschta RL, Komar PD and Bradley JB (eds) Gravel-bed Rivers in the Environment. Water Resources Publications, LLC: Highland Ranch, Colorado, 115-148

Balaguer-Puig M, Marqués-Mateu Á, Lerma JL, Ibáñez-Asensio S. 2017. Estimation of small-scale soil erosion in laboratory experiments with Structure from Motion photogrammetry. Geomorphology. DOI: 10.1016/j.geomorph.2017.04.035

Brasington J, Langham J, Rumsby B. 2003. Methodological sensitivity of morphometric estimates of coarse fluvial sediment transport. Geomorphology 53: 299-316. DOI: 10.1016/S0169-555X(02)00320-3

Brasington J, Smart RMA. 2003. Close range digital photogrammetric analysis of experimental drainage basin evolution. Earth Surface Processes and Landforms 28: 231-247. DOI: 10.1002/esp.480

Bruinsma J (ed). 2003. World agriculture: towards 2015/2030. An FAO perspective. Earthscan: London

Carrivick JL, Smith MW, Quincey DJ. 2016. Structure from Motion in the Geosciences. Wiley-Blackwell: Chichester, UK. DOI: 10.1002/9781118895818

This article is protected by copyright. All rights reserved. 
CDE/WOCAT FAO/LADA ISRIC. 2008. A Questionnaire for Mapping Land Degradation and Sustainable Land Management.

Cerdà A, Ibáñez S, Calvo A. 1997. Design and operation of a small and portable rainfall simulator for rugged terrain. Soil Technology 11: 163-170. DOI: 10.1016/S0933-3630(96)00135-3

Eltner A, Kaiser A, Castillo C, Rock G, Neugirg F, Abellán A. 2016. Image-based surface reconstruction in geomorphometry - merits, limits and developments. Earth Surface Dynamics 4: 359-389. DOI: 10.5194/esurf-4-359-2016

Erdogan S. 2009. A comparision of interpolation methods for producing digital elevation models at the field scale. Earth Surface Processes and Landforms 34: 366-376. DOI: 10.1002/esp.1731

FAO. 1980. Report on the first FAO/UNEP Expert Consultation on Desertification Assessment and mapping. Rome FAO. 2015. Status of the World's Soil Resources. Rome

FAO/UNEP/UNESCO. 1979. A provisional methodology for soil degradation assessment. Rome

Fisher PF, Tate NJ. 2006. Causes and consequences of error in digital elevation models. Progress in Physical Geography 30: 467-489. DOI: 10.1191/0309133306pp492ra

Fonstad MA, Dietrich JT, Courville BC, Jensen JL, Carbonneau PE. 2013. Topographic structure from motion: a new development in photogrammetric measurement. Earth Surface Processes and Landforms 38: 421-430. DOI: $10.1002 /$ esp.3366

Gessesse GD, Fuchs H, Mansberger R, Klik A, Rieke-Zapp DH. 2010. Assessment of erosion, deposition and rill development on irregular soil surfaces using close range digital photogrammetry. The Photogrammetric Record 25: 299-318. DOI: 10.1111/j.1477-9730.2010.00588.x

Gordon LM, Bennett SJ, Wells RR. 2012. Response of a soil-mantled experimental landscape to exogenic forcing. Water Resources Research 48. DOI: 10.1029/2012WR012283

Guo M, Shi H, Zhao J, Liu P, Welbourne D, Lin Q. 2016. Digital close range photogrammetry for the study of rill development at flume scale. CATENA 143: 265-274. DOI: 10.1016/j.catena.2016.03.036

Hänsel P, Schindewolf M, Eltner A, Kaiser A, Schmidt J. 2016. Feasibility of High-Resolution Soil Erosion Measurements by Means of Rainfall Simulations and SfM Photogrammetry. Hydrology 3: 38. DOI: 10.3390/hydrology3040038

Hao X, Ball B, Culley J, Carter M, Parkin G. 2008. Soil density and porosity. In: Carter MR and Gregorich EG (eds) Soil sampling and methods of analysis. Canadian Society of Soil Science: Boca Raton, FL, 743-759

Heng BCP, Chandler JH, Armstrong A. 2010. Applying close range digital photogrammetry in soil erosion studies. The Photogrammetric Record 25: 240-265. DOI: 10.1111/j.1477-9730.2010.00584.x

Hengl T, Heuvelink GBM, van Loon EE. 2010. On the uncertainty of stream networks derived from elevation data: the error propagation approach. Hydrology and Earth System Sciences 14. DOI: http://dx.doi.org/10.5194/hess-14-1153-2010

Heuvelink GBM. 1998. Error propagation in environmental modelling with GIS. Taylor \& Francis: London

Heuvelink GBM. 2005. Propagation of error in spatial modelling with GIS. In: Longley PA, Goodchild MF, Maguire DJ and Rhind DW (eds) Geographical Information Systems: Principles, Techniques, Management and Applications. Wiley: New York, 404

This article is protected by copyright. All rights reserved. 
James LA, Hodgson ME, Ghoshal S, Latiolais MM. 2012. Geomorphic change detection using historic maps and DEM differencing: The temporal dimension of geospatial analysis. Geomorphology 137: 181-198. DOI: 10.1016/j.geomorph.2010.10.039

James MR, Robson S. 2012. Straightforward reconstruction of 3D surfaces and topography with a camera: Accuracy and geoscience application. Journal of Geophysical Research: Earth Surface 117: 1-17. DOI: 10.1029/2011JF002289

James MR, Robson S. 2014. Mitigating systematic error in topographic models derived from UAV and groundbased image networks. Earth Surface Processes and Landforms 39: 1413-1420. DOI: 10.1002/esp.3609

James MR, Robson S, D'Oleire-Oltmanns S, Niethammer U. 2017a. Optimising UAV topographic surveys processed with structure-from-motion: Ground control quality, quantity and bundle adjustment. Geomorphology 280: 51-66. DOI: 10.1016/j.geomorph.2016.11.021

James MR, Robson S, Smith MW. 2017b. 3-D uncertainty-based topographic change detection with structure-frommotion photogrammetry: precision maps for ground control and directly georeferenced surveys. Earth Surface Processes and Landforms. DOI: 10.1002/esp.4125

Kasprak A, Wheaton JM, Ashmore PE, Hensleigh JW, Peirce S. 2015. The relationship between particle travel distance and channel morphology: Results from physical models of braided rivers. Journal of Geophysical Research: Earth Surface 120: 55-74. DOI: 10.1002/2014JF003310

Lane SN, Westaway RM, Hicks DM. 2003. Estimation of erosion and deposition volumes in a large, gravel-bed, braided river using synoptic remote sensing. Earth Surface Processes and Landforms 28: 249-271. DOI: $10.1002 /$ esp.483

Li Z, Zhu C, Gold C. 2005. Digital terrain modeling: principles and methodology. CRC Press: Boca Raton

Liu X, Hu J, M J. 2011. Quantitative Evaluation of Spatial Interpolation Models Based on a Data-Independent Method. In: Chen D (ed) Advances in Data, Methods, Models and Their Applications in Geoscience. InTech, 53-70. DOI: $10.5772 / 28365$

Luhmann T, Robson S, Kyle S, Boehm J. 2013. Close-Range Photogrammetry and 3D Imaging. Walter de Gruyter: Berlin/Boston. DOI: 10.1515/9783110302783

Micheletti N, Chandler JH, Lane SN. 2014. Investigating the geomorphological potential of freely available and accessible structure-from-motion photogrammetry using a smartphone. Earth Surface Processes and Landforms n/a-n/a. DOI: 10.1002/esp.3648

Micheletti N, Chandler JH, Lane SN. 2015. Structure from Motion (SfM) Photogrammetry. In: Clarke LE and Nield JM (eds) Geomorphological Techniques. British Society for Geomorphology: London

Milan DJ, Heritage GL, Large ARG, Fuller IC. 2011. Filtering spatial error from DEMs: Implications for morphological change estimation. Geomorphology 125: 160-171. DOI: 10.1016/j.geomorph.2010.09.012

Morgan RPC. 2005. Soil erosion and conservation. Blackwell: Oxford

Mosbrucker AR, Major JJ, Spicer KR, Pitlick J. 2017. Camera system considerations for geomorphic applications of SfM photogrammetry. Earth Surface Processes and Landforms. DOI: 10.1002/esp.4066

Nouwakpo SK, James MR, Weltz MA, Huang C-H, Chagas I, Lima L. 2014. Evaluation of structure from motion for soil microtopography measurement. The Photogrammetric Record 29: 297-316. DOI: 10.1111/phor.12072

Prosdocimi M, Burguet M, Di Prima S, Sofia G, Terol E, Rodrigo Comino J, Cerdà A, Tarolli P. 2017. Rainfall

This article is protected by copyright. All rights reserved. 
simulation and Structure-from-Motion photogrammetry for the analysis of soil water erosion in Mediterranean vineyards. Science of The Total Environment 574: 204-215. DOI: 10.1016/j.scitotenv.2016.09.036

Raper R, Erbach D. 1987. Bulk density measurement variability with core samplers. Transactions of the ASAE $\mathbf{3 0}$ : $878-881$

Rieke-Zapp DH, Nearing MA. 2005. Digital close range photogrammetry for measurement of soil erosion. The Photogrammetric Record 20: 69-87. DOI: 10.1111/j.1477-9730.2005.00305.x

UN. 1978. United Nations Conference on Desertification, 29 August-9 September 1977: round-up, plan of action, and resolutions. UN: New York

Vinci A, Todisco F, Brigante R, Mannocchi F, Radicioni F. 2017. A smartphone camera for the structure from motion reconstruction for measuring soil surface variations and soil loss due to erosion. Hydrology Research 48: 673-685. DOI: 10.2166/nh.2017.075

Wechsler SP, Kroll CN. 2006. Quantifying DEM uncertainty and its effect on topographic parameters. Photogrammetric Engineering \& Remote Sensing 72: 1081-1090. DOI: 10.14358/PERS.72.9.1081

Wenzel K, Rothermel M, Fritsch D, Haala N. 2013. Image acquisition and model selection for Multi-View Stereo. International Archives of the Photogrammetry, Remote Sensing and Spatial Information Sciences XL: 251258. DOI: 10.5194/isprsarchives-XL-5-W1-251-2013

Westoby MJ, Brasington J, Glasser NF, Hambrey MJ, Reynolds JM. 2012. "Structure-from-Motion" photogrammetry: A low-cost, effective tool for geoscience applications. Geomorphology 179: 300-314. DOI: 10.1016/j.geomorph.2012.08.021

Wheaton JM, Brasington J, Darby SE, Sear DA. 2010. Accounting for uncertainty in DEMs from repeat topographic surveys: improved sediment budgets. Earth Surface Processes and Landforms 35: 136-156. DOI: 10.1002/esp.1886

Williams RD. 2012. DEMs of Difference. Geomorphological Techniques 2: 1-17

This article is protected by copyright. All rights reserved. 


\section{Tables}

Table 1 Parameters used in Agisoft PhotoScan to generate dense point clouds.

\begin{tabular}{ll}
\hline Parameters & Value \\
\hline Alignment & \\
Accuracy & High \\
Generic preselection & Yes \\
Key point limit & 0 \\
Tie point limit & 0 \\
Optimization & \\
Parameters & $\mathrm{f}, \mathrm{b}_{1}, \mathrm{~b}_{2}, \mathrm{cx}, \mathrm{cy}, \mathrm{k} 1-\mathrm{k} 3, \mathrm{p} 1, \mathrm{p} 2$ \\
Dense point cloud & \\
$\begin{array}{l}\text { Quality } \\
\text { Filtering mode }\end{array}$ & High \\
Mesh & Mild \\
Surface type & Arbitrary \\
Source data & Dense \\
Interpolation & Disabled \\
Face count & High \\
\hline
\end{tabular}
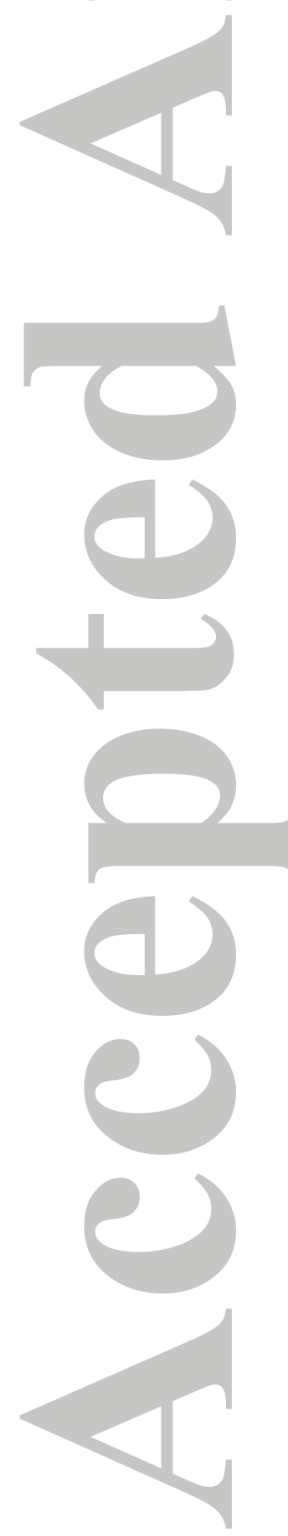

This article is protected by copyright. All rights reserved. 
Table 2 DEMs Errors.

\begin{tabular}{rrrrr}
\hline & $\begin{array}{r}\text { RMS GCP } \\
(\mathrm{mm})\end{array}$ & $\begin{array}{r}\text { Interpolation } \\
\text { error }(\mathrm{mm})\end{array}$ & $\mathrm{E}_{\mathrm{DEM}}(\mathrm{mm})$ & $\mathrm{E}_{\text {DoD }}(\mathrm{mm})$ \\
\hline DEM0 & 0.960 & 0.109 & 0.966 & \\
DEM1 & 0.699 & 0.103 & 0.707 & 1.197 \\
DEM2 & 0.971 & 0.101 & 0.976 & 1.205 \\
DEM3 & 0.530 & 0.114 & 0.543 & 1.117 \\
DEM4 & 0.525 & 0.100 & 0.535 & 0.762 \\
DEM5 & 0.611 & 0.107 & 0.620 & 0.819 \\
\hline
\end{tabular}

This article is protected by copyright. All rights reserved. 
Table 3 Volumes of erosion, deposition and net change, and mass of soil loss estimated from DoDs.

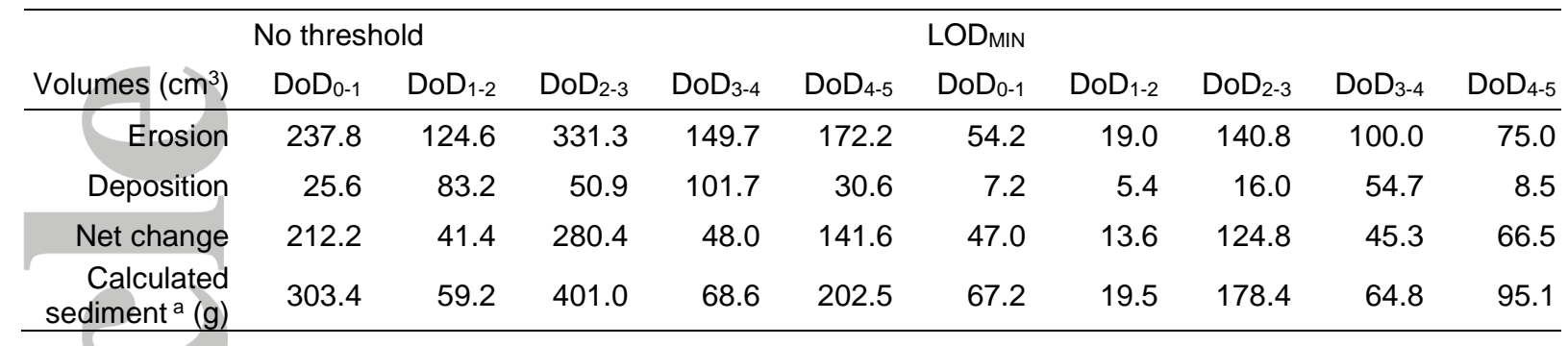

a Bulk density: $\rho_{b}=1.43 \mathrm{~g} / \mathrm{cm}^{3}$
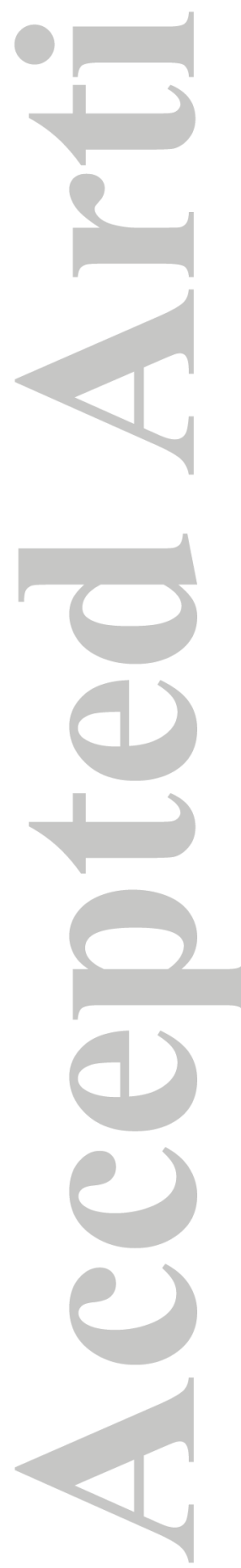
Table 4 Results of Monte Carlo simulations with $\mathrm{N}=10,50,100$ and 500 iterations. DEMs are obtained adding a random error based in values from Table 1.

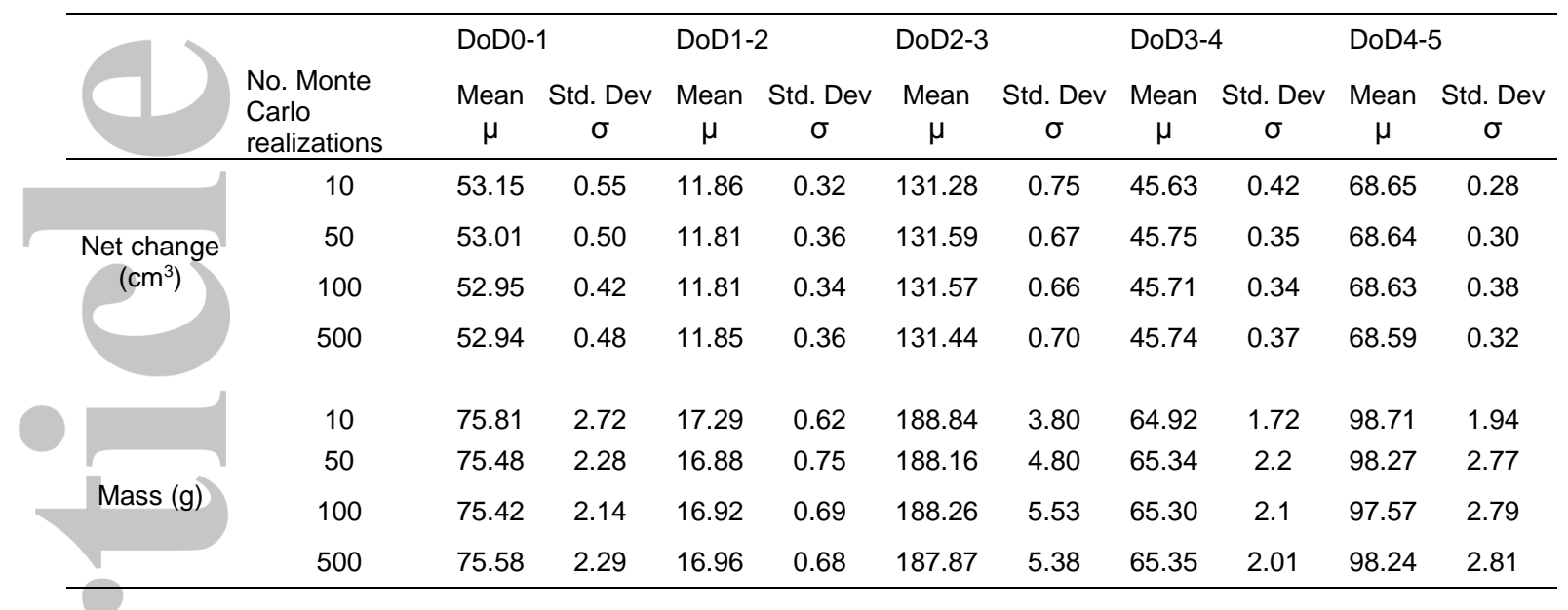


Table 5 Statistics of Monte Carlo simulations for soil loss estimation with $\mathrm{N}=500$ iterations.

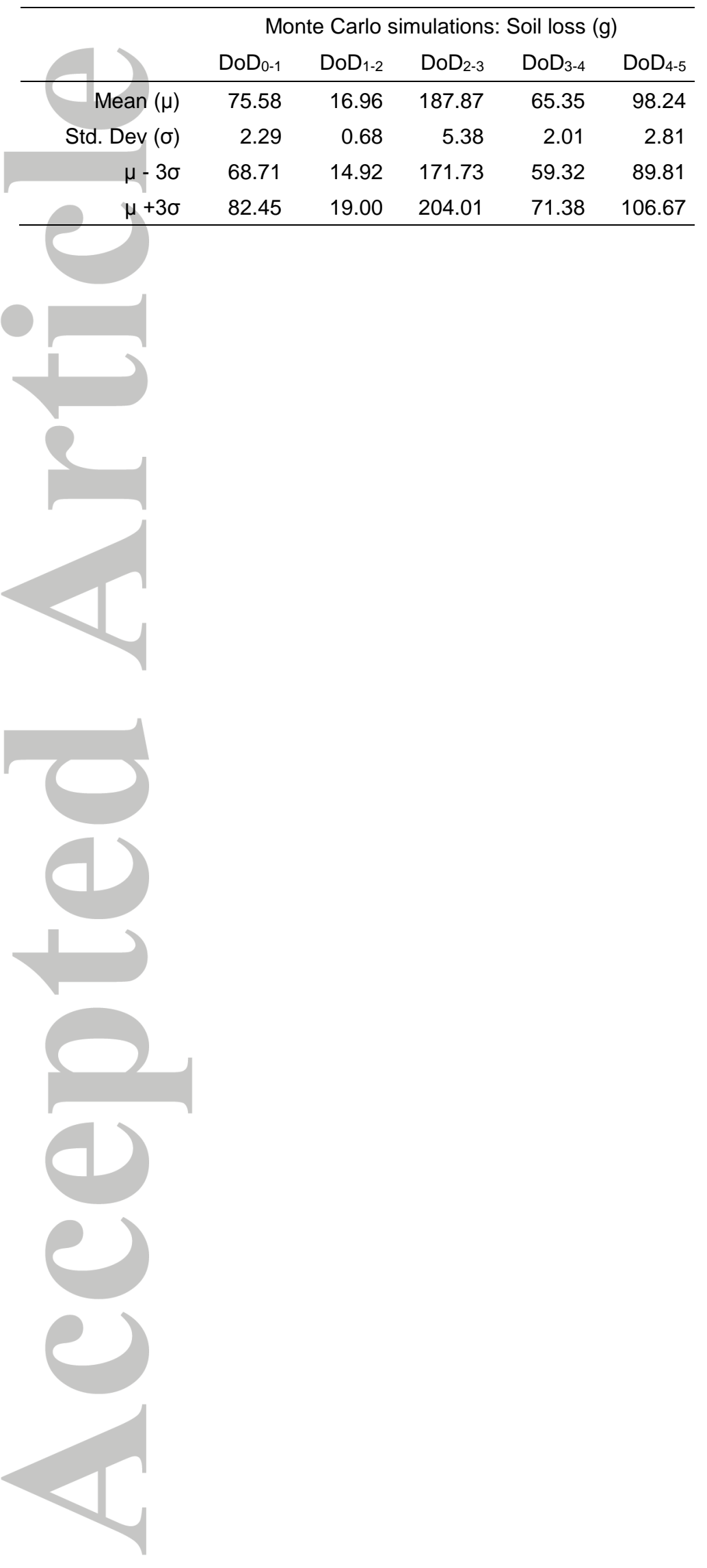

This article is protected by copyright. All rights reserved. 


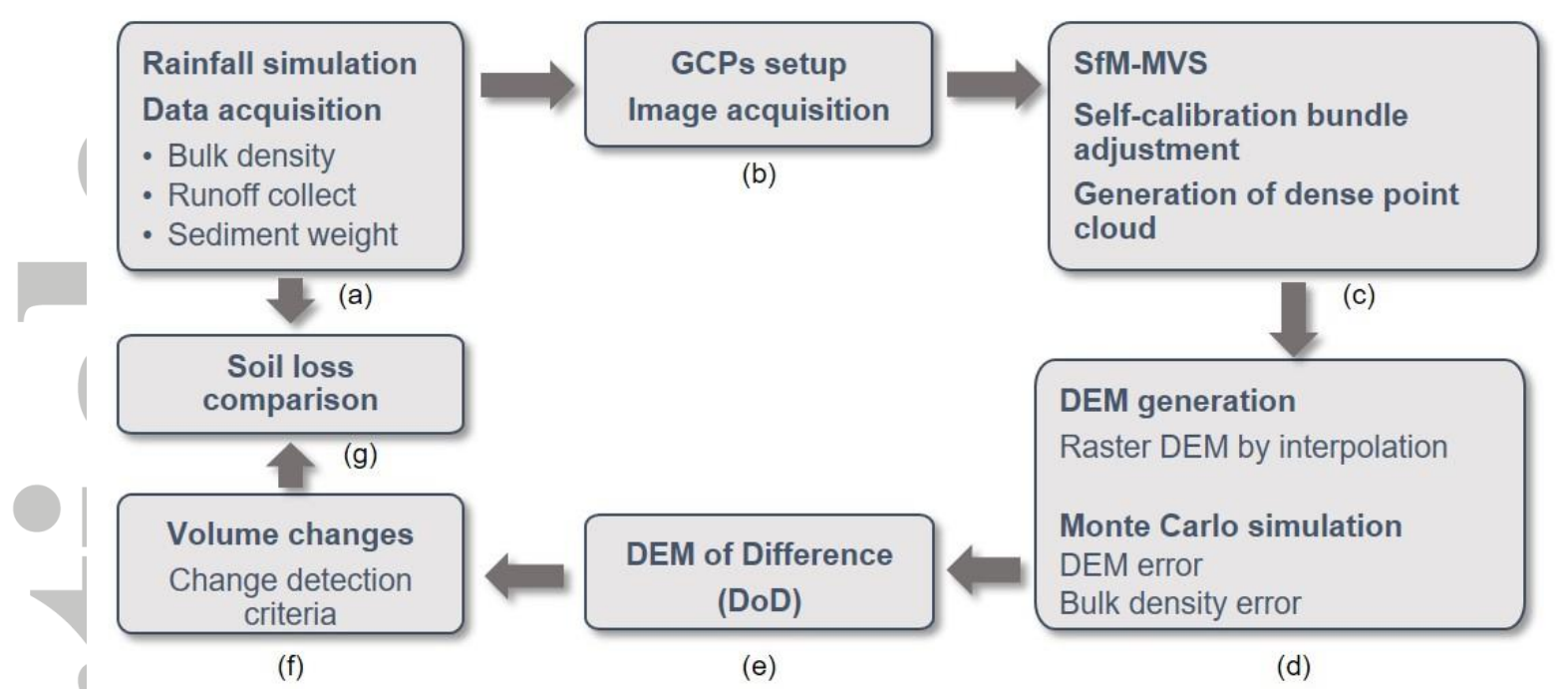

Figure 1 Working scheme: a) Rainfall simulation setup and data acquisition; b) GCPs setup and image acquisition; c) SfM image orientation and MVS dense point cloud; d) Raster DEM generation and Monte Carlo simulations; e) DoD calculation; f) Estimation of volumetric changes applying LODMIN; g) Comparison of volumetric estimation and soil collected.

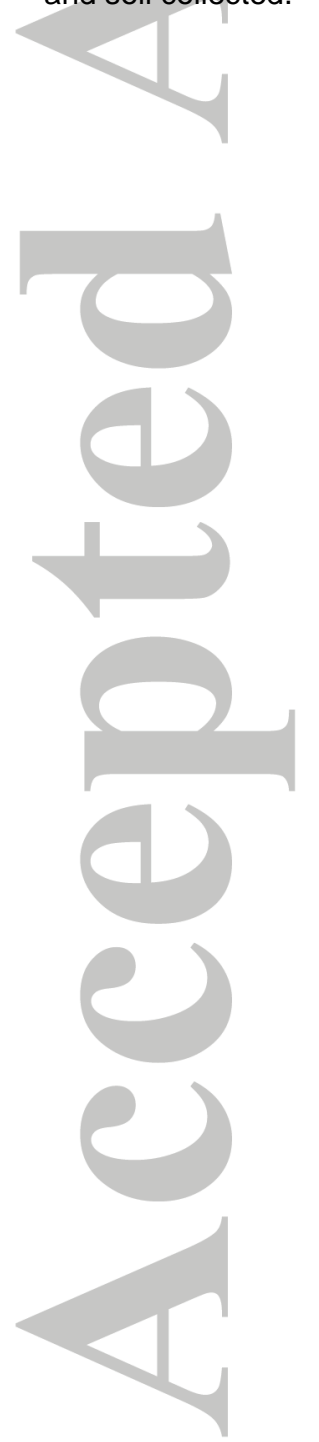




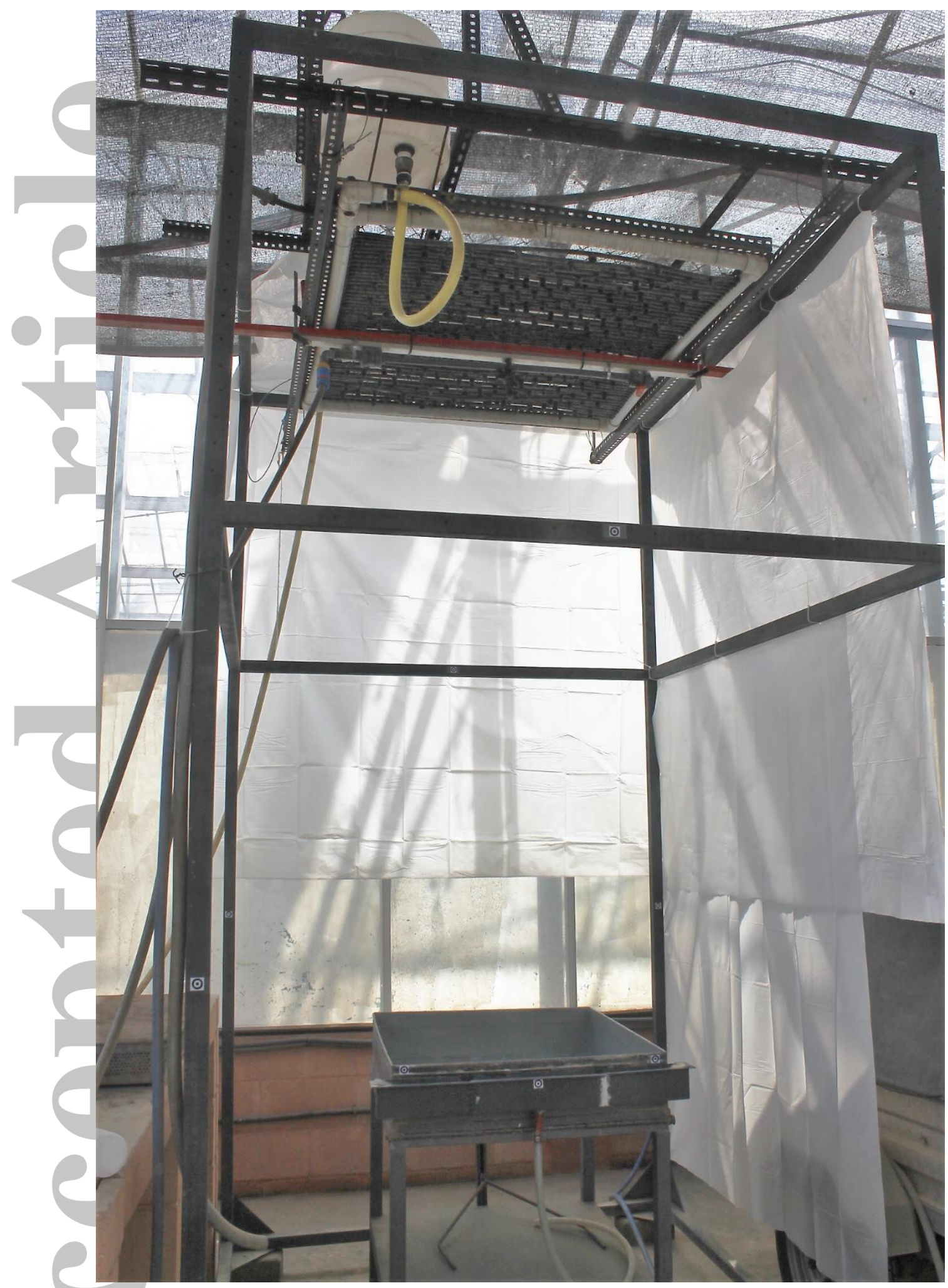

Figure 2 Rainfall simulator used in the experiment, showing the supporting structure, the soil box (bottom) and the droplet generator array (top). Note the distribution of GCPs at different heights and depths on the structure and soil box. The transparent plastic hose in the front of the box was used to collect runoff. There is another hose to collect infliltration which is not visible in the picture.

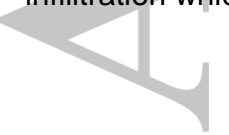

This article is protected by copyright. All rights reserved. 


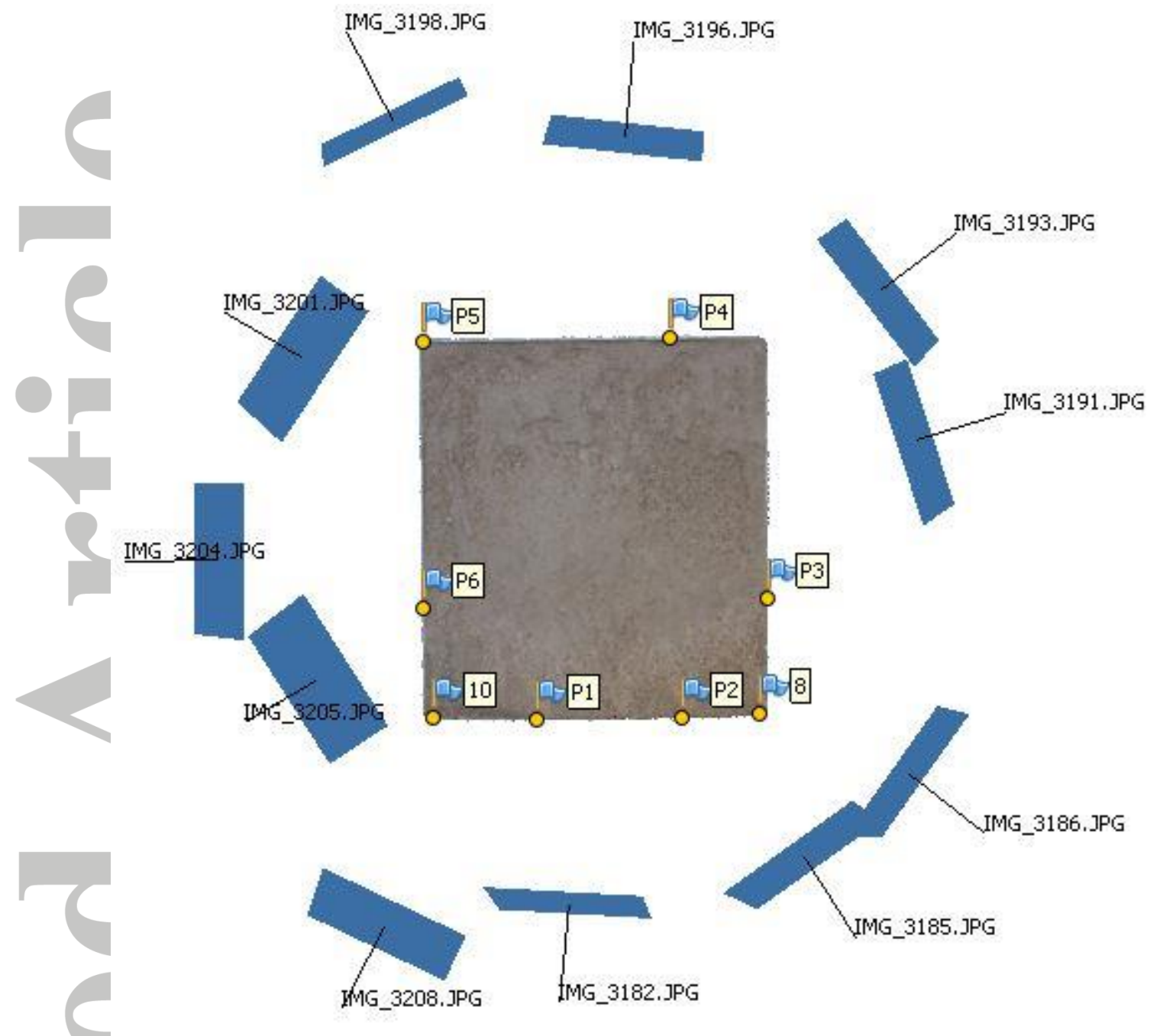

Figure 3 Convergent images oriented in space displaying the layout and the number of GCPs used on the soil box.

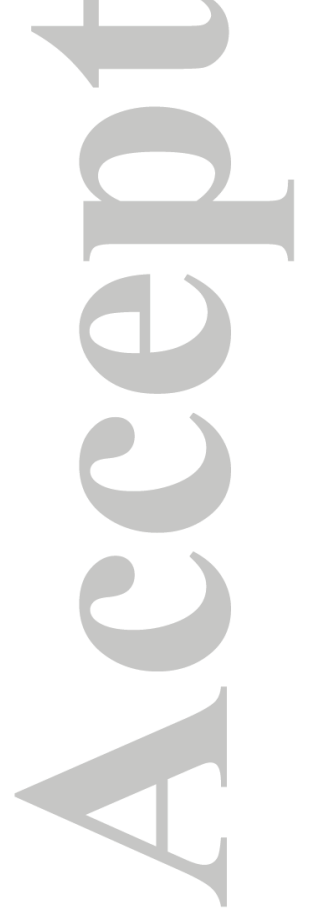

This article is protected by copyright. All rights reserved. 


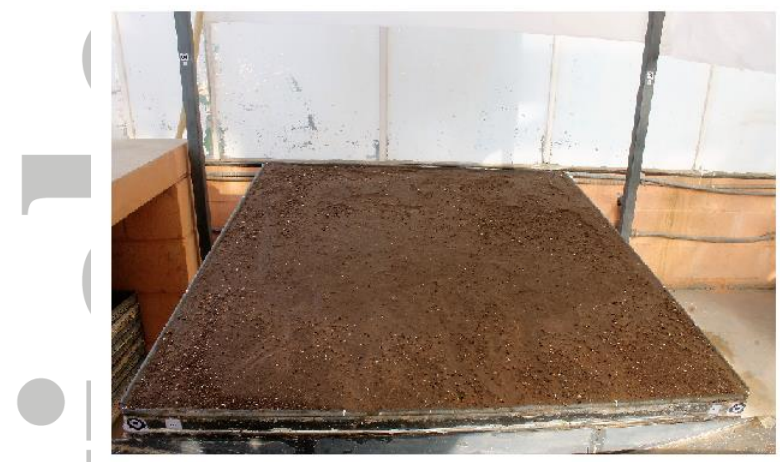

(a)

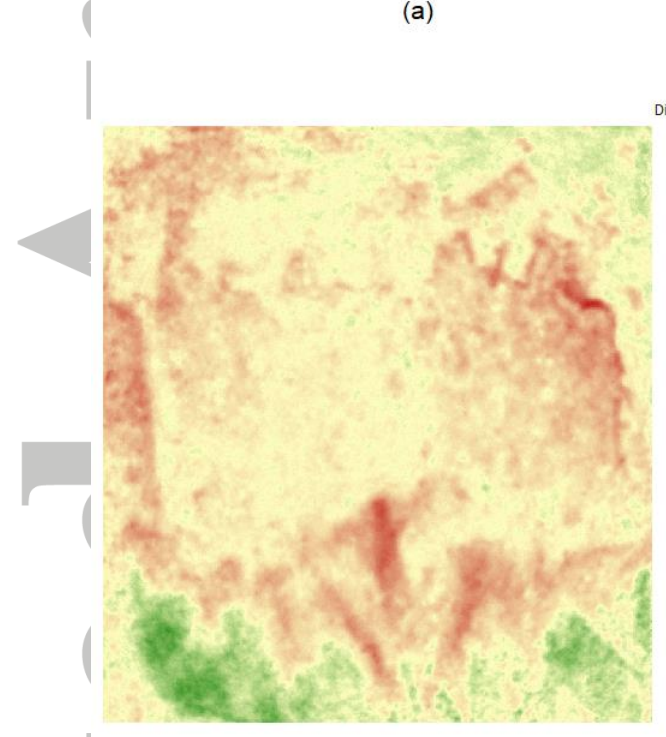

(c)

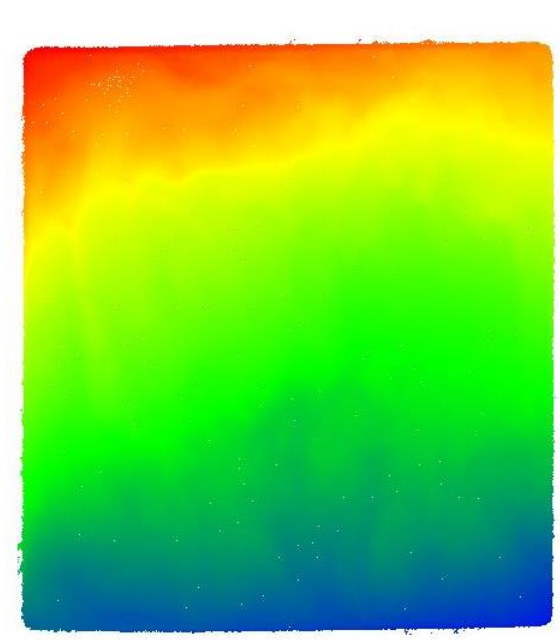

(b)
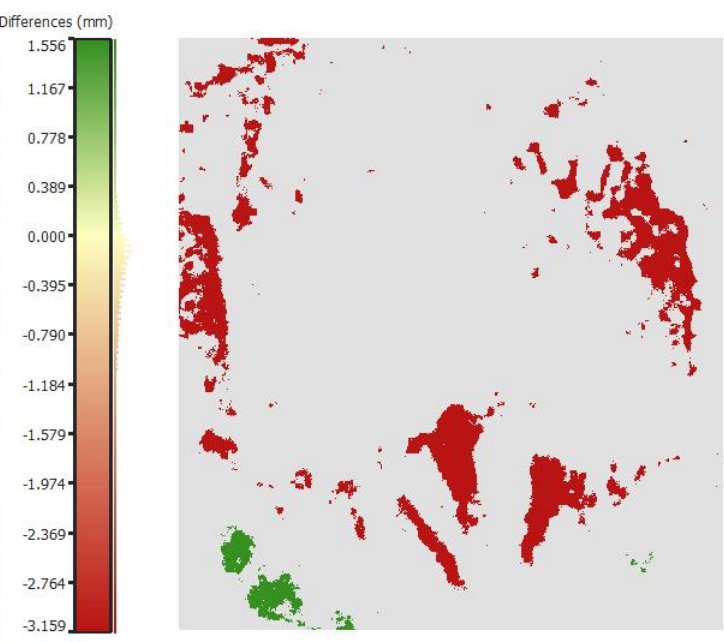

(d)

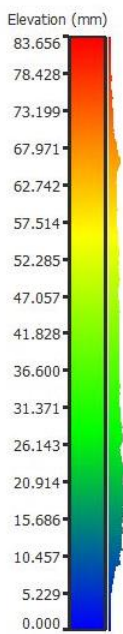

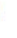

Figure 4 Results of GCD method for rain episode 5. a) Image of soil box after rain. b) SfM 3D point cloud of soil surface after rain. c) DEM of Differences between rain episodes 4 and $5\left(D_{0} D_{4-5}\right)$. d) Reclassified map after applying

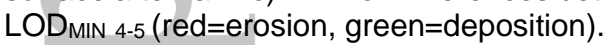




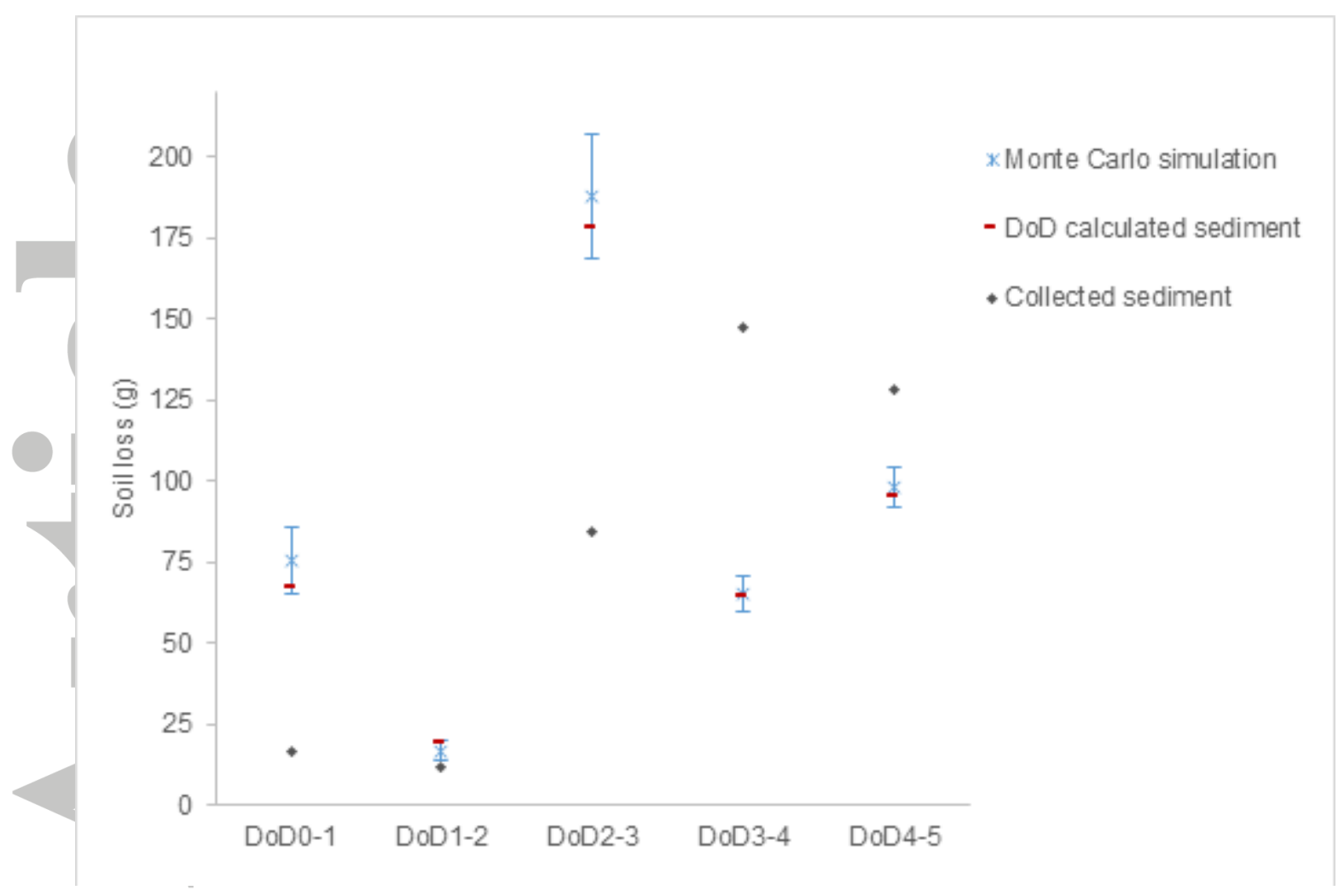

Figure 5 Soil loss collected, and estimated with DoDs and Monte Carlo simulations (error bars based on values of Table 5).

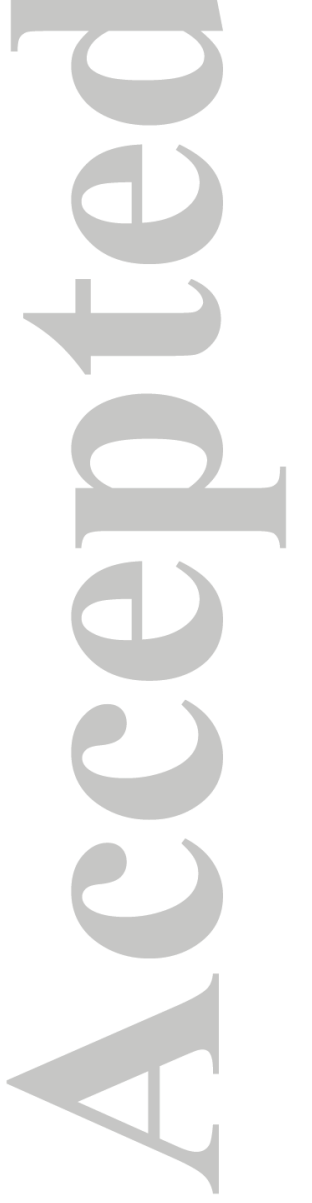

